\title{
Electro-Coagulation Treatment and De-oiling of Wastewaters Arising from Petroleum Industries
}

\author{
Sellami $\mathbf{M H}^{1 *}$, Loudiyi $\mathrm{K}^{2}$, Bellemharbet $\mathrm{K}^{1}$ and Djabbour $\mathbf{N}^{1}$ \\ ${ }^{1}$ Process Engineering Department, Laboratory of Process Engineering, Ouargla University 30000 Algeria
}

${ }^{2}$ Renewable Energies Laboratory (REL) Al Akhawayne University, Ifrane, Morocco

\begin{abstract}
Petroleum region of Haoud Berkaoui (HBK) is one of the first areas to provide great efforts in the field of environmental protection; this region has a resort of de-oiling, a recovery unit flaring gas, a potable water station and will soon have a wastewater treatment plant. Generally, wastewaters discharged by petroleum industries may contain hydrocarbons and suspended solids. The charge of wastewaters derived from petroleum industry exists in various forms: solutions, colloids and particles. It is important to treat this wastewater at low cost by electrocoagulation compared with traditional chemical treatments as conventional coagulation-flocculation process instead of reusing or re-injecting it directly into oil wells. The treatment by electro-coagulation was applied. This treatment provides two separate phases by settling or flotation. The electro-coagulation produces a similar separation as coagulation -flocculation using reagents such as $\mathrm{FeCl}_{3}$ or $\mathrm{Al}_{2}(\mathrm{SO} 4)_{3}$ but in this case, the coagulant is derived from the anodic dissolution of Aluminum. In this experiment we have studied the effect of several parameters, namely: the solution $\mathrm{pH}$, current intensity and clarification time on the process efficiency. The results showed that the Oil and Wastes Removal Efficiency (OWRE) was $79.61 \%$ for both current intensities of 0.3 and $0.65 \mathrm{~A}$ in a medium basic solution $\mathrm{pH}(9-11)$ and respectively after 100 and $80 \mathrm{~min}$ of clarification time. To see the impact of the treated water on vegetations, some irrigation tests have been conducted regarding two types of plants (date palm and shaft apocalyptic) for 13 months. The tests showed that the thick layer of $5 \mathrm{~cm}$ and fine particles diameter of dune sand removes most of the remaining oil. The layer that fills the basin surrounding the shaft is removed and replaced every 03 months. So, fine dune sand plays the role of biological filter. The little garden plants appear and grow normally.
\end{abstract}

Keywords: De-oiling; Wastewater; Electro-coagulation; Environment; Colloids; Emulsion; Dune sand

Abbreviations: HBK: Petroleum region of Haoud Berkaoui (Ouargla/Algeria); OWRE: Oil and Wastes Removal Efficiency (\%).

\section{Nomenclature}

Turbidity $_{\text {in }}=$ Wastewater turbidity before treatment

Turbidity $_{\text {out }}=$ Wastewater turbidity after treatment.

\section{Introduction}

The discharge of petroleum products into the wild leads to the proliferation of microorganisms able to grow on hydrocarbons and their degradation products. Their number is chronically much higher in the polluted areas and increases after intake of oil in sites without contamination.

Industrial wastewaters discharged by petroleum industries contains: oil, heavy metals and chemicals used in the process of oil separation and treatment. These wastewaters are a source of soil, water and air pollution, and lead a mortal danger to the ecosystem.

In petroleum plants, the removal of oil and suspended solids is primary and relatively performed by purely physical separation methods such as CPI (density difference), decantation, filtration, centrifugation etc; nevertheless, the fine particles behave as a remaining colloidal suspension and require separation by chemical flocculation. The latter consists in neutralizing the colloidal suspension by the addition of an electrolyte causing particles agglomeration and consequently their flocculation.

The biodegradation is also one of the primary mechanisms leading to the elimination of oil from the environment; however, wastewaters are usually difficult to degrade and have high turbidity and toxicity. Thus, physical separation step is important to ensure that the wastewater being treated before reuse or release to wild [1]. Coagulation and flocculation is one of the methods used to treat industrial wastewaters. Colloidal particles in nature normally carry charges on their surface which lead to the stabilization of suspension. The attractive force between particles, exist in case of colloidal particles in suspension, but the electrostatic repulsion of surface charges opposes the particles to come together and form agglomerates. The principal mechanism controlling the stability of both hydrophobic and hydrophilic particles is the electrostatic repulsion [2]

Addition of chemicals can change the surface property of such colloidal particles or lead to precipitate dissolved material so as to facilitate the separation of solids by filtration or settling. The conversion of stable state dispersion to the unstable state is expressed as coagulation and flocculation $[3,4]$.

The coagulation, is the process whereby destabilization of a given colloidal suspension or solution is taking place. The role of coagulation is to overcome the factors that promote the stability of a given system.

"Corresponding author: Sellami $\mathrm{MH}$, Process Engineering Department Laboratory of Process Engineering, Ouargla University 30000 Algeria, E-mail sellami2000dz@gmail.com

Received December 25, 2015; Accepted July 18, 2016; Published July 26, 2016

Citation: Sellami MH, Loudiyi K, Bellemharbet K, Djabbour N (2016) ElectroCoagulation Treatment and De-oiling of Wastewaters Arising from Petroleum Industries. J Pet Environ Biotechnol 7: 290. doi:10.4172/2157-7463.1000290

Copyright: @ 2016 Sellami MH, et al. This is an open-access article distributed under the terms of the Creative Commons Attribution License, which permits unrestricted use, distribution, and reproduction in any medium, provided the original author and source are credited. 
It is realized by the use of appropriate chemicals, usually Aluminum or iron salts called coagulant agents. The flocculation refers to the induction of destabilized particles in order to come closer, to coalesce and thereby, to form large agglomerates, which can be generally separated easier by gravity settling [5].

The agglomerates formed by coagulation are compact and loosely tied, whereas the flocs are of larger size, strongly attached and porous in case of flocculation. In mineral processing industries, the range of application of flocculants is much greater than the coagulants.

The load of wastewaters discharged from petroleum industries exists in various forms: solutions, colloids and particles. It is important to treat this wastewater at low cost instead of reusing or injecting it directly into oil wells. In order to improve the physicochemical processes of destabilization of emulsions, the treatment by electrocoagulation was used. Typically, wastewater is treated by coagulationflocculation using reagents such as $\mathrm{FeCl}_{3}$ or $\mathrm{Al}_{2}(\mathrm{SO} 4)_{3}$. This treatment provides two separate phases by settling or flotation [6].

The electro-coagulation produces a similar separation but, in this case the coagulant is derived from the anodic dissolution of Aluminum. In addition, the treatment lends itself to automation, conservation issues reagents are negligible because the anodes can last long and the response time to a change in flow rate or concentration of the effluent load remains very fast [7].

For good knowledge of pollution level of the area, M. Valipour et al. [8-10] proposed an Environmental flow diagram (EFD) based on energy reference system (RES) and process flow diagram (PFD) for each industrial company because without the exact information about quantity and quality of pollution sources, decrease or eliminate industrial pollutions are difficult. Environmental flow diagram was carried out by authors to find and locate sources of pollutants, and explaining impact of solutions to the energy optimization and reduces environmental pollutants.

Some investigators on wastewater treatments in Ouargla University (southern Algeria) use a new promising technique for wastewater treatment; this technique is the use of dune sand as a biological filter. The use of this local material as a filtration support for domestic wastewater treatment demonstrated its efficiency at pilot scale. Using two layers of dune sand in various column heights, they carried out measurements of porosities, suspended matter and fouling timecourse for a week. Nevertheless, dune sand filter receives considerably amounts of suspended matter, causing biological clogging, decreasing therefore the filter porosity $[11,12]$.

During electrostatic oil desalting process in treatment units, about $5 \%$ of the volume of the crude oil is added as fresh water (wash water) to reach and extract emulsified salts. Haoud Berkaoui region (HBK) is one of the most important areas for the production of crude oil. So, the amount of wastewater discharged from this region's refinery is significant; its spill in nature without treatment or its reinjection in wells to increase the reservoir pressure is polluting our ecosystem. The treatment of this water becomes an obligation and the choice of a soft and cheap technique remains one of the solutions we have for the moment to decrease the risk that this wastewater exerts on the environment.

In this experiment we have optimized the conditions of destabilizing emulsions by studying several parameters, namely: the solution $\mathrm{pH}$, intensity of applied current and clarification time. The Oil and Wastes Removal Efficiency (OWRE) was calculated using:

$$
\operatorname{OWRE}(\%)=\left(\frac{\text { Turbidity }_{\text {in }}-\text { Turbidity }_{\text {out }}}{\text { Turbidity }_{\text {in }}}\right) \times 100
$$

Finally, irrigation tests of treated water using fine particles of dune sand as biological filter in private garden plants during 13 months have been carried out.

\section{Materials and Methods}

Two experiments were performed for removal of wastes and hydrocarbons by using electrochemical cell with Aluminum electrodes supplied by an electric generator (Figure 1). In the first experiment, the current intensity was varied and the solution $\mathrm{pH}$ was maintained as possible at a constant value (without the addition of any acid or base). In the second experiment the current intensity was fixed and the solution $\mathrm{pH}$ was varied. Finally the Oil and Wastes Removal Efficiency (OWRE) was calculated.

\section{Sampling}

Sampling operations must be performed quickly to avoid any change in wastewater quality. The water was taken either in clean glass bottles (rinsed and dried), or in polyethylene bottles. To avoid any change in the characteristics of the wastewater between sampling and analysis, the samples were stored at standard temperature in the dark and were sent to the laboratory within 24 hours after collection. Different samples were taken from the same wastewater and various parameters were analyzed and determined, such as solution $\mathrm{pH}$, conductivity, turbidity, different ions concentrations, different pollutants elements and heavy metals. Because of analytical samples were taken during the week, the primary test ( $\mathrm{pH}$, turbidity etc ...) were not exactly the same; so we have used for each experiment a different wastewater. We were interested on clarification time and Oil and wastes removal efficiency only. The Table 1 below given as an example, shows the mean values of key parameters of the wastewater $\left(\mathrm{N}^{\circ} 1\right)$ used in the first experiment compared with standard values authorized by the official gazette of Algeria shown in the same table [13].

\section{First experiment (Effect of current intensity)}

Firstly the initial $\mathrm{pH}$ and turbidity were measured (Table $\mathrm{N}^{\circ} 1$ ). A sample of one liter of oily wastewater was placed in the electrochemical cell. A generator for supplying the cell was used, the current intensity was adjusted to $\mathrm{I}=0.25 \mathrm{~A}$ with a voltmeter.

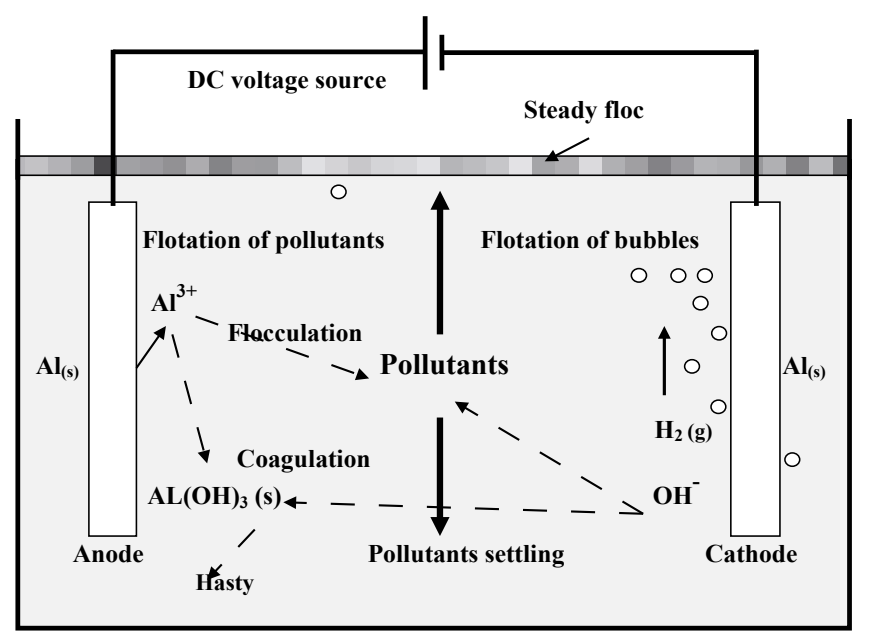

Figure 1: Schematic principle of electro-coagulation. 
Citation: Sellami MH, Loudiyi K, Bellemharbet K, Djabbour N (2016) Electro-Coagulation Treatment and De-oiling of Wastewaters Arising from Petroleum Industries. J Pet Environ Biotechnol 7: 290. doi:10.4172/2157-7463.1000290

Page 3 of 6

\begin{tabular}{|c|c|c|}
\hline Parameter & $\begin{array}{l}\text { Concentration } \\
(\mathrm{mg} / \mathrm{l})\end{array}$ & $\begin{array}{c}\text { Maximal value authorized } \\
\text { [13] }\end{array}$ \\
\hline$\left(\mathrm{Ca}^{2+}\right)(\mathrm{mg} / \mathrm{l})$ & 10832 & ---- \\
\hline$\left(\mathrm{Mg}^{2+}\right)(\mathrm{mg} / \mathrm{l})$ & 2733 & --- \\
\hline$\left(\mathrm{Fe}^{2+}\right) \quad(\mathrm{mg} / \mathrm{l})$ & 601 & 3 \\
\hline$\left(\mathrm{Cl}^{-}\right) \quad(\mathrm{mg} / \mathrm{l})$ & 69393 & ---- \\
\hline$\left(\mathrm{SO}_{4}^{2-}\right)(\mathrm{mg} / \mathrm{l})$ & 411 & --- \\
\hline $\mathrm{pH}$ & 6.05 & 6.5 à 8.5 \\
\hline Conductivity ( $\mu \mathrm{s} / \mathrm{cm})$ & 1131 & ---- \\
\hline $\begin{array}{l}\text { Total salinity expressed in } \\
(\mathrm{NaCl})(\mathrm{mg} / \mathrm{l})\end{array}$ & 115000 & --- \\
\hline Turbidity NTU & 209 & ---- \\
\hline $\mathrm{SM} \quad(\mathrm{mg} / \mathrm{l})$ & 169 & 40 \\
\hline$\left(\mathrm{BOD}_{5}\right)(\mathrm{mg} / \mathrm{l})$ & 3.91 & 35 \\
\hline$(\mathrm{COD}) \quad(\mathrm{mg} / \mathrm{l})$ & 948 & 120 \\
\hline$\left(\mathrm{NO}_{3}^{-}\right) \quad(\mathrm{mg} / \mathrm{l})$ & 2.10 & --- \\
\hline$\left(\mathrm{PO}_{4}{ }^{3-}\right) \quad(\mathrm{mg} / \mathrm{l})$ & 3.49 & 10 \\
\hline$(\mathrm{Pb}) \quad(\mathrm{mg} / \mathrm{l})$ & 4.01 & 0.5 \\
\hline$(\mathrm{Cu}) \quad(\mathrm{mg} / \mathrm{l})$ & 0.09 & 0.5 \\
\hline$(\mathrm{Cd}) \quad(\mathrm{mg} / \mathrm{l})$ & 0.34 & 0.2 \\
\hline$(\mathrm{Zn}) \quad(\mathrm{mg} / \mathrm{l})$ & 22 & 3 \\
\hline$(\mathrm{Mn}) \quad(\mathrm{mg} / \mathrm{l})$ & 115 & 1 \\
\hline
\end{tabular}

Table 1: Key parameters values of wastewater $\left(\mathrm{N}^{\circ} 1\right)$ and standard values authorized.

$5 \mathrm{~g}$ of $\mathrm{Na}_{2} \mathrm{SO}_{4}$ was weighed, and then added to improve the solution conductivity. The duration of clarification time is two hours $(120$ $\mathrm{min}$ ). The solution $\mathrm{pH}$ and the turbidity were measured every $20 \mathrm{~min}$, respectively by $\mathrm{pH}$-meter and spectrophotometer. The experiment was repeated for each current $(\mathrm{I}=0.3 \mathrm{~A}-0.35 \mathrm{~A}-0.40 \mathrm{~A}-0.45 \mathrm{~A}-0.50 \mathrm{~A}-$ $0.55 \mathrm{~A}-0.60 \mathrm{~A}-0.65 \mathrm{~A}-0.7 \mathrm{~A})$.

\section{Second experiment (Effect of solution $\mathrm{pH}$ )}

For acid solution ( $\mathrm{pH}$ is between 4 and 6), sulfuric acid $\left(\mathrm{H}_{2} \mathrm{SO}_{4}\right.$ ) was used. For a bit basic solution ( $\mathrm{pH}$ between 6 and 9), sodium hydroxide $(\mathrm{NaOH})$ was used because the solution $\mathrm{pH}$ at the entrance is usually close to 6 .

For medium basic solution ( $\mathrm{pH}$ between 9 and 11), also sodium hydroxide $(\mathrm{NaOH})$ was used.

After the first experiment we have chosen two best current intensities which given minimum of turbidity and maximum of efficiency for acidic and basic solution. The clarification time was measured for each of the best intensities.

Finally the better of the two current intensities was chosen to give: the lower turbidity, the maximum oil and wastes removal efficiency and the lower clarification time.

\section{Results and Discussion}

To avoid graphical clutter during the study of the current intensities effect (first experiment), each series of 10 curves has been divided in two parts of 5 curves.

\section{Effect of current intensity}

Figures $2 \mathrm{a}$ and $2 \mathrm{~b}$ present the effect of the current intensity on the solution $\mathrm{pH}$. As shown, generally the solution $\mathrm{pH}$ increased slowly from 6 (weakly acid) to reach neutral or weakly basic solution after clarification time $(120 \mathrm{~min})$. For the lower intensity $(\mathrm{I}=0.25 \mathrm{~A})$ the variation of solution $\mathrm{pH}$ was insignificant because the solution remained weakly acid.

As displayed in Figures $3 a$ and $3 b$, the turbidity decreases with processing time from 209 NTU to less than 125 NTU. The lower turbidity observed was $21 \mathrm{NTU}$ for I $=0.65 \mathrm{~A}$ obtained after $40 \mathrm{~min}$, succeeded by $28 \mathrm{NTU}$ for I=0.3 A obtained at the end of experiment (120 min). Generally the increase of turbidity observed after $40 \mathrm{~min}$ of experiment was due to the solution $\mathrm{pH}$ which becomes weakly acid and allows the dissolution of Aluminum. This was remarkably observed for the current intensity of $0.25 \mathrm{~A}$.

Figures $4 \mathrm{a}$ and $4 \mathrm{~b}$ show the effect of the current intensity on the efficiency of removing oil and wastes vs. time for different current

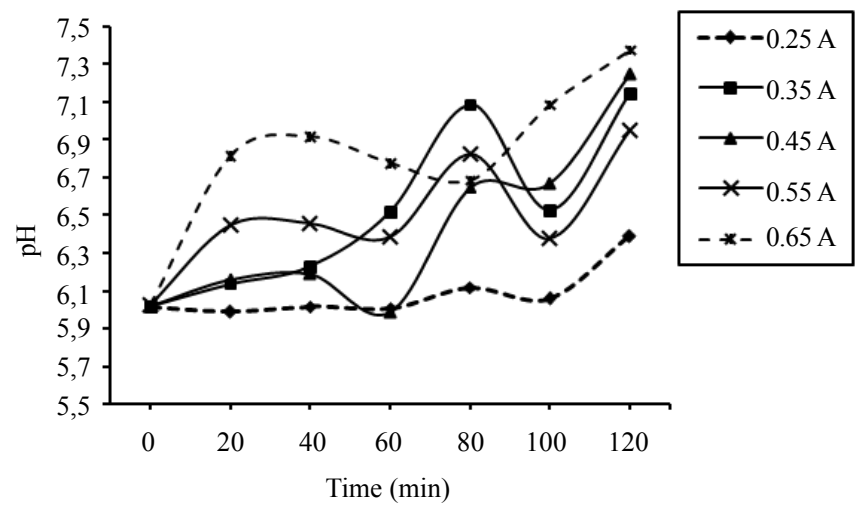

Figure 2a: Effect of current intensity on the solution $\mathrm{pH}$.

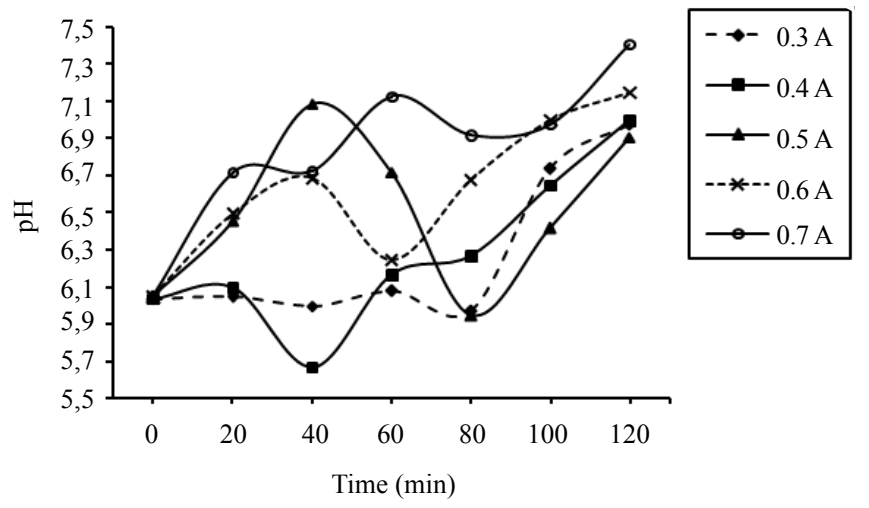

Figure 2b: Effect of current intensity on the solution $\mathrm{pH}$.

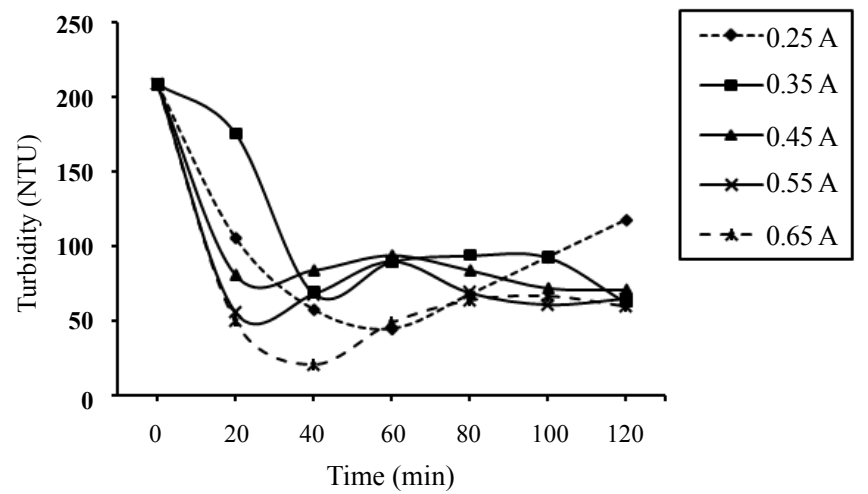

Figure 3a: Variation of the turbidity vs. time for different current intensities. 


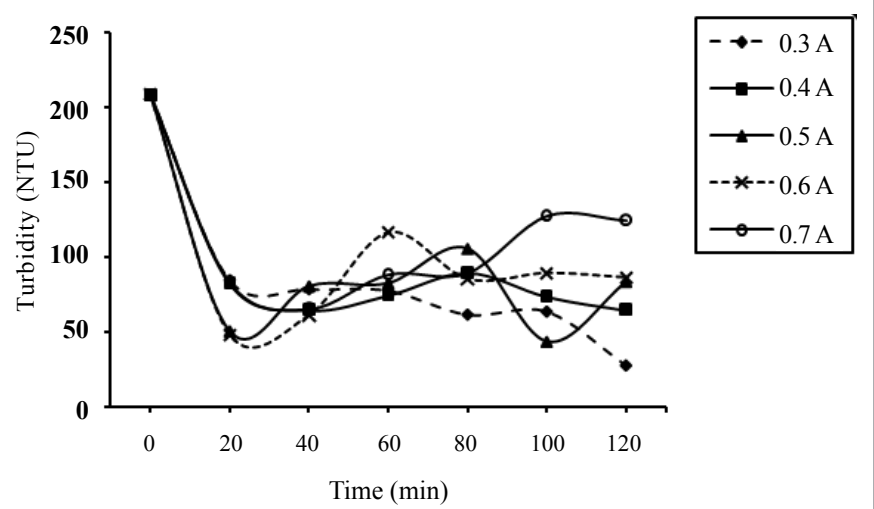

Figure 3b: Variation of the turbidity vs. time for different current intensities.

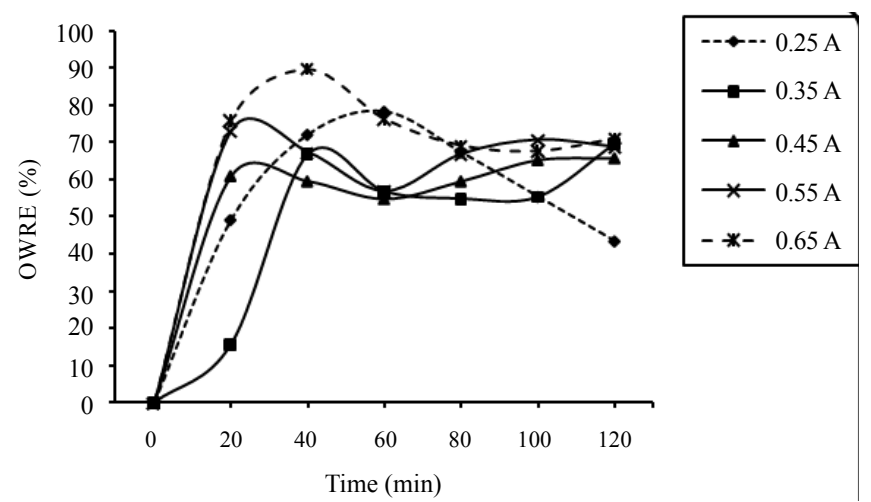

Figure 4a: Variation of oil and wastes removal efficiency (OWRE) vs. processing time for different current intensities.

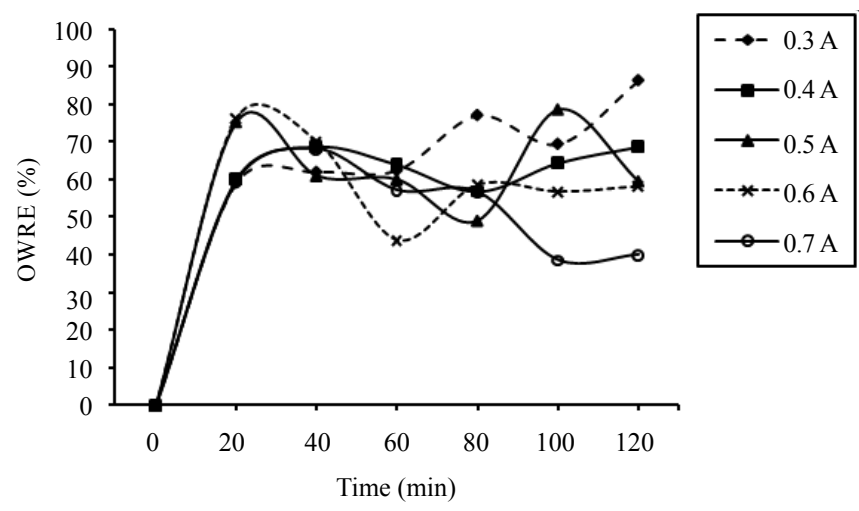

Figure 4b: Variation of oil and wastes removal efficiency (OWRE) vs. processing time for different current intensities.

intensities. As shown, and from (OWRE) equation, the current intensities which give the lower turbidity must inevitably give the high efficiency. The high values recorded for the (OWRE) were: 89.95 and $86.6 \%$ respectively for $\mathrm{I}=0.65 \mathrm{~A}$ after $40 \mathrm{~min}$ and $\mathrm{I}=0.3 \mathrm{~A}$ after $120 \mathrm{~min}$. So from Figures 3 and 4, we concluded that the best current intensities recorded were $0.65 \mathrm{~A}$ and $0.3 \mathrm{~A}$.

\section{Effect of solution $\mathrm{pH}$}

In this experiment the wastewater $\left(\mathrm{N}^{\circ} 2\right)$ used has $157 \mathrm{NTU}$ of initial turbidity and $\mathrm{pH}=5.98$.
During this second experiment, and for choosing the better current intensity between 0.65 and $0.3 \mathrm{~A}$, we changed the solution $\mathrm{pH}$ by adding sulfuric acid to obtain acidic solution and by adding sodium hydroxide to obtain basic solution. For each $\mathrm{pH}$ condition, we have measured the turbidity and calculated the (OWRE) for the two intensities cited.

pH range (4-6): Figure 5 displays the measured turbidity according to processing time in medium acidic solution ( $\mathrm{pH}$ range: 4-6) for the two chosen intensities ( 0.3 and $0.65 \mathrm{~A}$ ). The initial turbidity (157 NTU) decreased for the both current intensities to reach 59 and 34 NTU respectively for 0.3 and $0.65 \mathrm{~A}$ after $120 \mathrm{~min}$. Between 60 and $100 \mathrm{~min}$, applying $0.65 \mathrm{~A}$ of current intensity, increased the turbidity slightly from 67 to $103 \mathrm{NTU}$, this was due to the dissolution of Aluminum in this acidic environment.

Figure 6 presents the oil and wastes removal efficiency variation vs. processing time for the two chosen intensities for the same $\mathrm{pH}$ solution range (4-6). The maximum (OWRE) obtained were $78.34 \%$ and $62.42 \%$ respectively for 0.65 and $0.3 \mathrm{~A}$, that it was observed at the end of experiment (120 min).

pH range (6-9): For a neutral or slightly basic environment, it is clear from Figure 7 that the turbidity decreased all of a sudden from 157 to $45 \mathrm{NTU}$ for the current intensity of $0.3 \mathrm{~A}$ only after $20 \mathrm{~min}$, but increased again between 40 and $100 \mathrm{~min}$ to decrease again at the end of experiment reaching its lower value ( 35 NTU).

On the contrary, and for the current intensity of $0.65 \mathrm{~A}$, the

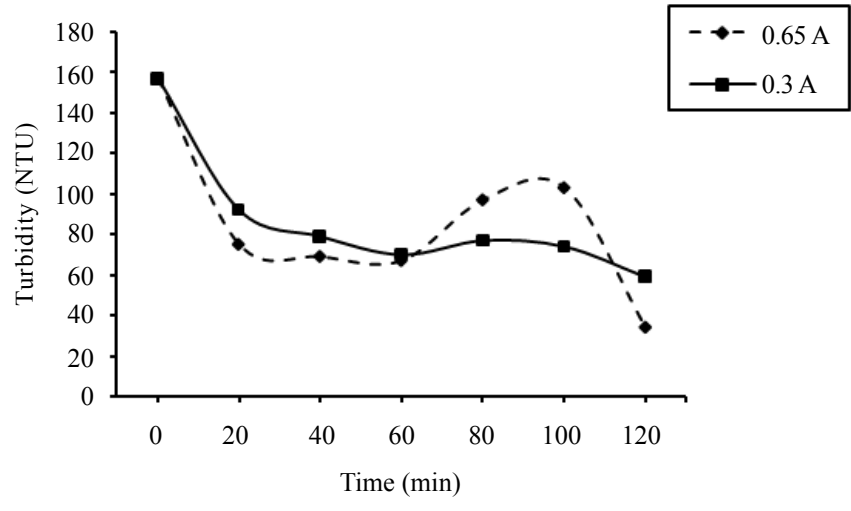

Figure 5: Variation of the turbidity vs. time for the two current intensities $(0.65$ and $0.3 \mathrm{~A}$ ) - Solution $\mathrm{pH}(4-6)$.

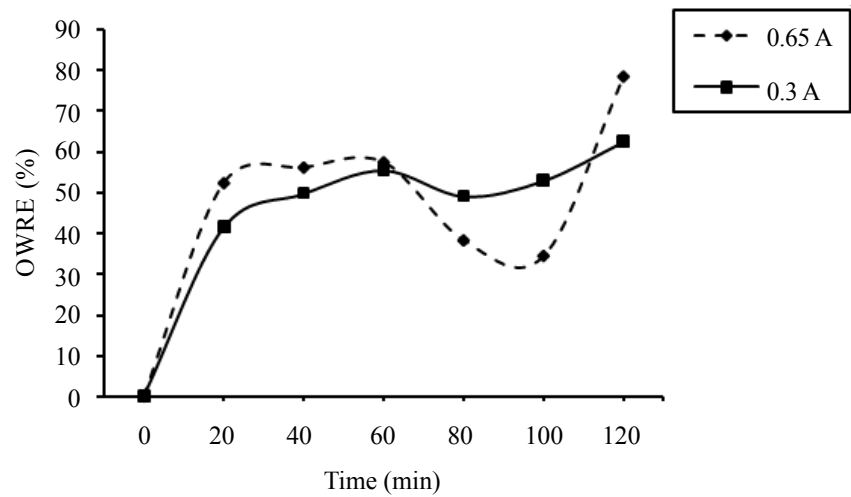

Figure 6: Variation of the OWRE vs. processing time for the two curren intensities $(0.65$ and $0.3 \mathrm{~A})$ - Solution $\mathrm{pH}(4-6)$. 


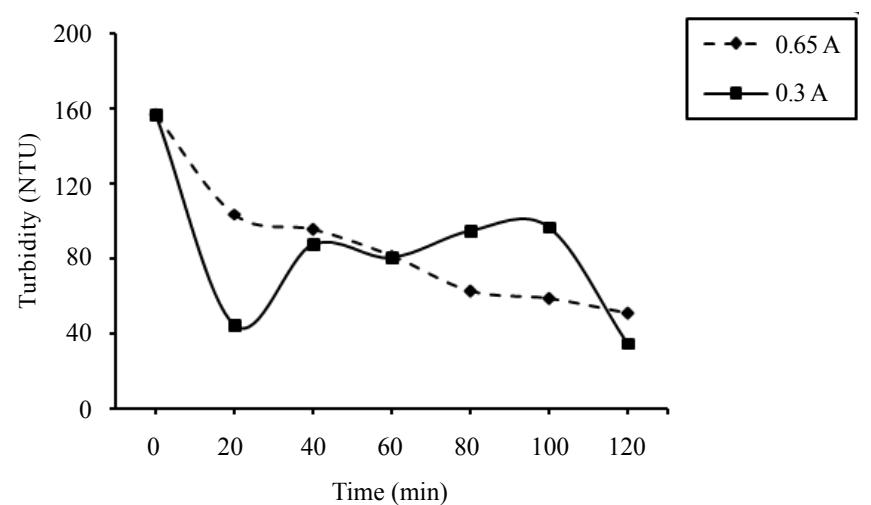

Figure 7: Variation of the turbidity vs. time for the two current intensities $(0.65$ and $0.3 \mathrm{~A})$ - Solution $\mathrm{pH}(6-9)$.

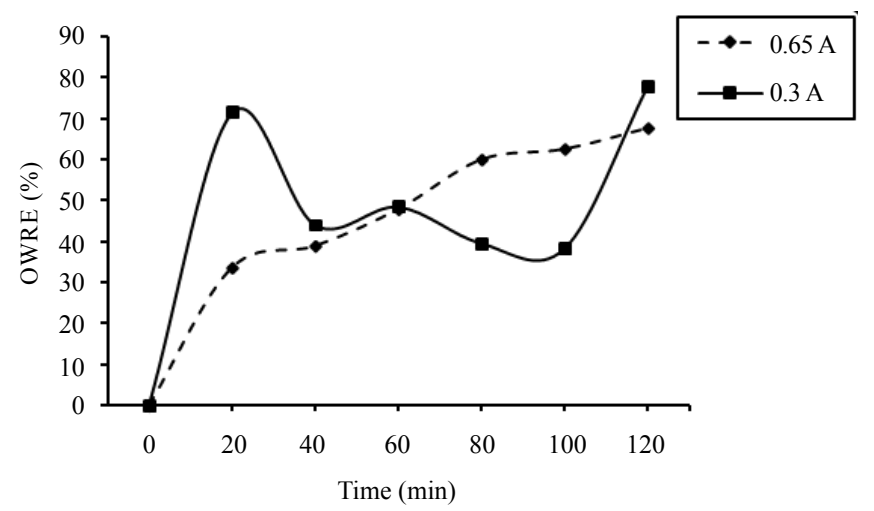

Figure 8: Variation of the OWRE vs. processing time for the two current intensities (0.65 and $0.3 \mathrm{~A})$ - Solution $\mathrm{pH}(6-9)$.

turbidity decreased in a regular manner throughout the experiment until 51 NTU.

Figure 8 illustrates the variation of oil and wastes removal efficiency vs. processing time for the two chosen intensities for a neutral or slightly basic environment. In these environment conditions, it is clear that the current intensity of $0.3 \mathrm{~A}$ has given the best (OWRE). So, after 20 min of treatment time, the latter reached $71.33 \%$ and decreased again, finally it reached $77.7 \%$ after clarification time $(120 \mathrm{~min})$. On the contrary, the (OWRE) calculated for the current intensity of $0.65 \mathrm{~A}$ after clarification time (120 min) was only $67.51 \%$.

pH range (9-11): In the absence of any production of turbidity due to dissolution of Aluminum in acidic solution, it can be seen from Figure 9 that the turbidity decreased almost regularly for the both of current intensities. The lower turbidity value recorded for the both intensities was $32 \mathrm{NTU}$, after $80 \mathrm{~min}$ and $100 \mathrm{~min}$ respectively for 0.65 and $0.3 \mathrm{~A}$ of current intensity. At the end of treatment time, the turbidities recorded for the two intensities were not interesting.

Figure 10 further clarifies the Figure 9; the best (OWRE) calculated were after 80 and $100 \mathrm{~min}$ of processing time respectively for 0.65 and $0.3 \mathrm{~A}$ of current intensity. Obviously and respectively, 79.62 and $79.61 \%$ of oil and wastes removal efficiency has been calculated.

\section{Vegetation Tests}

In aim to see the impact and the behavior of the treated water towards plants, daily irrigation tests have been conducted in a little private garden on two types of plants (shaft apocalyptic and date palm) for 13 months. The tests showed that the layer of $5 \mathrm{~cm}$ thickness and $0.08 \mathrm{~mm}$ of average particles diameter of dune sand removes most of remaining oil and impurities. The sand layer that fills the basin surrounding the shaft is removed and replaced every 03 months. So, we can deduce that fine dune sand plays the role of natural filter. After 13 months of control, garden plants appear and grow normally.

Finally, we suggest the filtration of wastewaters through fine particles of dune sand primary to any chemical treatment. Encouraging trials are in progress in this axis, as well as biological and mineral tests on the eventual remaining heavy metals and hydrocarbons contained in plants.

\section{Conclusion}

In order to remove the emulsified oil and wastes from wastewater arising out of petroleum industries, a treatment by electro-coagulationflotation using Aluminum electrodes with a voltage of $12 \mathrm{~V}$ and a contact time of $120 \mathrm{~min}$ was realized and gave good results. It allowed the reduction of:

a) $78.34 \%$ of oil and wastes using $0.65 \mathrm{~A}$ of current intensity in an environment of solution $\mathrm{pH}$ (4-6) after $120 \mathrm{~min}$ of clarification time.

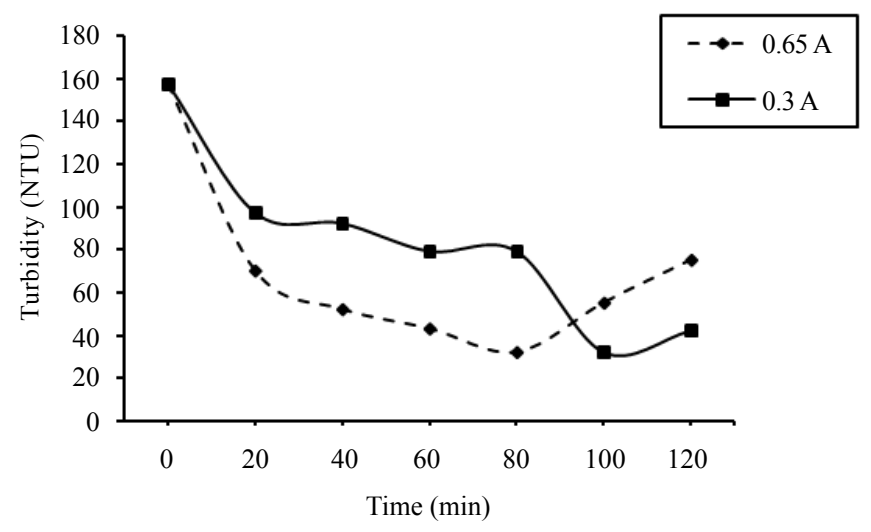

Figure 9: Variation of the turbidity vs. time for the two current intensities $(0.65$ and $0.3 \mathrm{~A})$ - Solution $\mathrm{pH}(9-11)$.

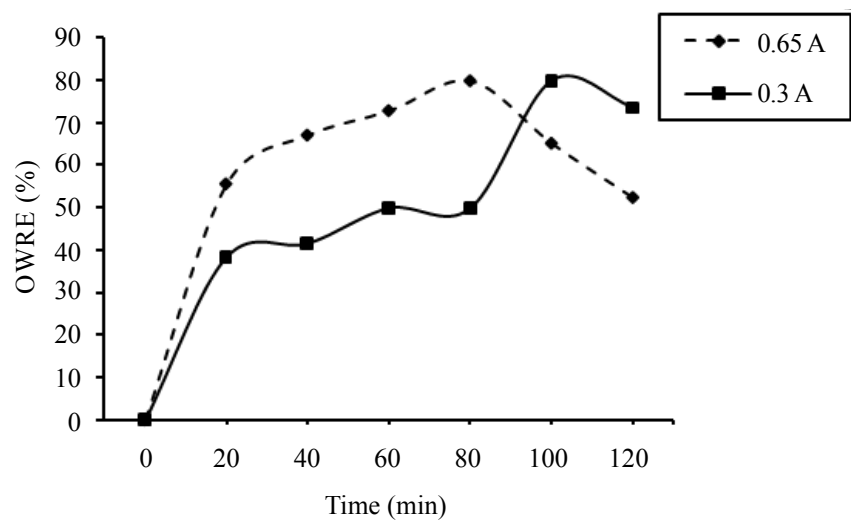

Figure 10: Variation of the OWRE vs. processing time for the two current intensities - Solution $\mathrm{pH}(9-11)$. 
Citation: Sellami MH, Loudiyi K, Bellemharbet K, Djabbour N (2016) Electro-Coagulation Treatment and De-oiling of Wastewaters Arising from Petroleum Industries. J Pet Environ Biotechnol 7: 290. doi:10.4172/2157-7463.1000290

Page 6 of 6

b) $77.70 \%$ of oil and wastes using $0.3 \mathrm{~A}$ of current intensity in an environment of solution $\mathrm{pH}(6-9)$ after $120 \mathrm{~min}$ of clarification time.

c) $79.62 \%$ of oil and wastes using $0.65 \mathrm{~A}$ of current intensity in an environment of solution $\mathrm{pH}$ (9-11) after $80 \mathrm{~min}$ of clarification time.

d) $79.61 \%$ of oil and wastes using $0.3 \mathrm{~A}$ of current intensity in an environment of solution $\mathrm{pH}(9-11)$ after 100 min of clarification time.

The four results are close in turbidity term, but are different in term of clarification time and solution $\mathrm{pH}$. The last two seem to be the best results; their Oil and Wastes Removal Efficiencies are almost equal; nevertheless, they require an economic discussion: either save time or gain electrical energy. To save electrical energy and lose $20 \mathrm{~min}$ of clarification time implies the use of $0.3 \mathrm{~A}$ of current intensity in medium basic environment. A simple observation shows that the use of $0.65 \mathrm{~A}$ instead of $0.3 \mathrm{~A}$ of current intensity leads to excessive consumption of electrical energy despite the gain of $20 \mathrm{~min}$ of processing time.

In aim to see the impact of the treated water on plants, daily irrigation tests were conducted within a little private garden on two types of plants (date palm and the shaft apocalyptic) for more than a year. The tests showed that the layer of about $5 \mathrm{~cm}$ thickness and $0.08 \mathrm{~mm}$ of particles diameter of fine dune sand removes most of the remaining oil and impurities. The sand layer that fills the basin surrounding the shaft is sometimes removed and replaced by new dune sand four times per year. After 13 months of control, garden plants appear and grow normally. Thus, we suggest the filtration of wastewaters through dune sand primary to any chemical treatment because of encouraging trials recorded in this axis; as well as biological and mineral tests on the probable remaining traces of hydrocarbons and heavy metals contained within plants.

\section{Acknowledgment}

The authors thank the personnel of Sonatrach Laboratory /HBK/Algeria, for their valuable cooperation in doing the experimental tests.

\section{References}

1. Wang Y, Gao B, Yue Q (2011) Effect of viscosity, basicity and organic content of composite flocculants on the discoloration performance and mechanism for reactive dyeing wastewater. J EnvironSci 23: 1626-1633.

2. Montgomery JM (1985) Principles and design water treatment. Wiley J \& Sons New York p: 116

3. Hughes MA (1990) Coagulation and flocculation, Part-1, in solid-liquid separation, (3rdedn). L. Svarosky, (ed.). Butterworth \& Co (Publishers) Ltd p: 74

4. Gregory J (1993) Stability and flocculation of suspensions, in Proc. Solid-Liquid Dispersions. P. Ayazi Shamlou (ed.) Butterworth-Heinemann Ltd. - Ch. 3.

5. Bratby $J(2006)$ Coagulation and flocculation in water and wastewater treatment. (2ndedn) IWA Publishing, London. pp: 50-68.

6. Hassen Sellami M (2015) Treatment and reuse of wastewaters discharged by petroleum industries (HMD/Algeria). Interna J waste res 6: 1-6.

7. Cansado (1997) Water treatment by electro-flocculation. Montréal-UniversityQuebec, Canada.

8. Valipour M, Seyyed MM, Reza V, Ehsan R (2012) Air, water, and soil pollution study in industrial units using environmental flow diagram. J Basic Appl Sci Res 2: $12365-12372$.

9. Valipour M, Seyyed MM, Reza V, Ehsan R (2013) Deal with environmental challenges in civil and energy engineering projects using a new technology. $J$ Civ \& Enviro Eng 3: 1-6.

10. Valipour M, Seyyed MM, Reza V, Ehsan R (2013) A new approach fo environmental crises and its solutions by computer modeling. Civilica 3: 1-6.

11. Ammour F (2008) Use of dune sands as a bio-filter for the wastewater treatment in Ouargla City (Algeria). Public knowledge project pp: 1-7.

12. Touil Y, Yamina G, Rachid I, Abdeltif A (2014) Biological filtration on sand of dunes filters fouling. Energy Procedia 50: 471-478.

13. Gezette (2006) Official Gazette of the Democratic and Popular Republic of Algeria $\mathrm{N}^{\circ} 26$ 